\title{
PENERAPAN METODE BAMBOO DANCING UNTUK MENINGKATKAN HASIL PEMAHAMAN TEKS MATERI QIRO'AH MAHASISWA
}

\author{
Muhammad Syaifullah, Nailul Izzah, Hernisawati \\ Institut Agama Islam Ma'arif NU Metro Lampung \\ email: muhammadsyaifullah121285@gmail.com
}

\begin{abstract}
The purpose of Qiro'ah (reading) lessons is to train students to be able to understand texts individually. The application of an exciting and enjoyable learning strategy by a Lecturer that involves students actively in the process of understanding the reading content, either independently or in groups. Current learning models such as contextual learning and cooperative learning can also be adapted for learning to read. Improving students' Qiro'ah (reading) mastery results is a general objective of this study with a cooperative dancing type approach. The specific objectives of this study are (1) Describe the Qiro'ah learning process (reading) use of the bamboo dancing method of PBA students at IAIM NU Metro, and (2) Describe the results of increasing mastery of Qiro'ah learning (reading) of PBA students) use of the bamboo dancing method. The design uses PTK with John Elliot Models. PBA third semester students are the subjects in this study. Information about the activities of lecturers and students and the results of the initial and final test scores in each cycle is the data in this study. Test questions, observation sheets, and interview guidelines are the instruments used in this study. Using steps is collecting data, reducing data, presenting data, and concluding research results. Whereas Planning, implementing, observing, and reflecting are the stages in this research. The results of the application of Qiro'ah learning using the bamboo dancing method in this study are the increased mastery of understanding in reading texts that is significant from each cycle and the initial tests before the action. The average grade on the initial test before action is 67 increased in cycle 179 as well as increasing again in cycle 291 . So, it can be concluded that there is an increase in the understanding of students' Qiro'ah texts in each cycle.
\end{abstract}

Keywords: Learning Model; Cooperative Bamboo Dancing; Reading. 


\begin{abstract}
Abstrak
Tujuan pelajaran Qiro'ah (membaca) yaitu melatih Mahasiswa untuk dapat memahami teks secara individual. Penerapan strategi pembelajaran yang menarik dan menyenangkan oleh seorang Dosen yang melibatkan Mahasiswa secara aktif dalam proses pemahaman isi bacaan, baik secara mandiri atau secara berkelompok. Model-model pembelajaran mutakhir seperti pembelajaran kontekstual dan pembelajaran kooperatif juga bisa diadaptasi untuk pembelajaran membaca. Peningkatan hasil penguasaan Qiro'ah mahasiswa merupakan tujuan umum dari penelitian ini dengan pendekatan kooperatif tipe bamboo dancing. Sedangkan tujuan khusus dalam penelitian ini yaitu (1) mendeskripsikan proses pembelajaran Qiro'ah mahasiswa PBA IAIM NU Metro dengan metode bamboo dancing, dan (2) memaparkan hasil dari peningkatan penguasaan pemahaman Qiro'ah mahasiswa dengan metode bamboo dancing. Rancangan penelitian menggunakan PTK model John Elliot. Subjek dalam penelitian ini adalah mahasiswa PBA semester tiga. Sedangkan data pada penelitian ini berupa informasi tentang aktivitas dosen dan mahasiswa dan hasil nilai tes awal dan tes akhir dalam tiap siklusnya. Soal tes, lembar observasi, dan pedoman wawancara merupakan instrumen yang digunakan dalam penelitian ini. Langkah-langkah yang digunakan yaitu dengan mengumpulkan data, mereduksi data, menyajikan data, dan menyimpulkan hasil penelitian. Sedangkan tahapan melalui perencanaan, pelaksanaan, observasi, dan refleksi. Hasil penerapan pembelajaran Qiro'ah dengan menggunakan metode bamboo dancing dalam penelitian ini adalah meningkatnya penguasaan pemahaman dalam membaca teks yang signifikan dari setiap siklusnya dan dari tes awal sebelum tindakan. Rata-rata kelas pada tes awal sebelum tindakan ialah 67 meningkat di siklus 1 yaitu 79 begitu juga meningkat lagi di siklus 2 yaitu 91. Sehingga dapat disimpulkan bahwa adanya peningkatan terhadap pemahaman teks Qiro'ah mahasiswa di setiap siklusnya.
\end{abstract}

Kata Kunci: Model Pembelajaran; Kooperatif Bamboo Dancing; Qiro'ah.

\title{
A. Pendahuluan
}

Suatu proses tindakan yang dibuat oleh seseorang dengan sendirinya, sehingga membuat suatu perubahan dari keadaan sebelumnya yang ditimbulkan oleh lainnya dari sebuah pengalaman dan inilah yang dimaksud dengan hakikat dari belajar. ${ }^{1}$ Proses peristiwa belajar mengajar terdapat banyak metode dan banyak model, sehingga seorang guru menjadi pemeran utama dalam pendidikan. Joyce \& Weil menjadikan 4 kelompok, yaitu: perkembangan pribadi, proses informasi, interaksi sosial dan modifikasi tingkah laku. ${ }^{2}$

Sejak dini, seorang anak dapat dididik untuk dapat membaca dan menulis al-Qur'an. Sehingga menjadi suatu alternatif dari orang tua

${ }^{1}$ A. Samsuddin Makmun, Psikologi Kependidikan (Bandung: Remaja Rosdakarya, 2009), h. 157.

2 Bruce Joys, Marsha Weil, dan Emily Calhoun, Models of Teaching (Yogyakarta: Pustaka Pelajar, 2009), h. 3. 
mempercayai lembaga-lembaga pendidikan seperti di Taman Pendidikan al-Qur'an bagi orang tua yang kurang dapat meluangkan waktu serta minimnya kemampuan yang dimiliki. ${ }^{3}$ Dalam hal ini, merupakan dasar awal untuk anak-anak dalam mengenal bahasa Arab.

Bahasa Arab adalah bahasa peradaban, sebagai bahasa Islam yang mempersatukan umat Islam di dunia, dan sebagai bahasa internasional. Sehingga, bagi masyarakat Indonesia masih merasa asing meskipun mayoritas penduduknya beragama Islam. ${ }^{4}$ Oleh karena itu, bagi masyarakat Indonesia sangat tidak mungkin untuk mendalami ajaran agama Islam dengan tidak menguasai bahasa Arab dengan baik. ${ }^{5}$

Seorang khalifah Umar bin Khattab radhiyallahu 'anhu berkata:

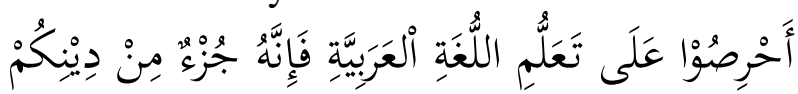

Artinya: "Seriuslah mempelajari bahasa Arab, karena bahasa Arab itu merupakan bagian dari agama kalian." 6

Oleh karena itu, seorang Dosen dalam menerapkan metode pada proses pembelajaran harus menggunakan metode pembelajaran yang aktif dan menyenangkan sehingga seorang mahasiswa tidak merasakan bosan dan siap dalam menerima pelajaran, sehingga dapat penyerapan materi secara baik. Kiranya seorang guru atau dosen menggunakan beberapa bentuk variasi metode pada proses belajar sehingga tidak adanya mahasiswa merasakan kebosanan sehingga mampu menerima materi pelajaran dalam keadaan siap.

Menurut Peneliti di lapangan terjadi beberapa masalah yang ada ketika penyampaian materi pada mata kuliah Qiro'ah (membaca), termasuk kurangnya partisipasi Dosen dalam perancangan dan penerapan variasi model pembelajaran yang aktif dan menyenangkan sehingga Mahasiswa sehingga kurang maksimalnya dalam memahami materi Qiro'ah. Pembelajaran pasif dengan terfokuskan kepada seorang Dosen dan tidak melibatkan mahasiswanya untuk aktif menjadi penyebab kurang maksimalnya Mahasiswa untuk memahami dan menerima materi Qiro'ah tersebut.

\footnotetext{
${ }^{3}$ Muhammad Syaifullah, "Penerapan Metode An-Nahdliyah Di TPQ Al-Barokah Dan Metode Iqra' Di TPQ Al-Ikhlas Hadimulyo Timur Metro Pusat Lampung Dalam Kemampuan Membaca Al-Qur'an," Jurnal Iqra' : Kajian Ilmu Pendidikan 2, no. 1 (2017): 131-64, https://doi.org/10.25217/ji.v2i1.96.

${ }^{4}$ Umar Fauzi, "Pembentukan Kemampuan Berbahasa Pada Anak Usia Prasekolah (Studi Deskriftif Tentang Pengenalan Bahasa Arab Sejak Dini" (Skripsi, Purwokerto, STAIN Purwokerto, 2003), h. 3.

${ }^{5}$ Tayar Yusuf dan Syaiful Anwar, Metodologi Pengajaran Agama dan Bahasa Arab (Jakarta: Raja Grafindo Persada, 1997), h. 7.

${ }^{6}$ A. Munawari, Belajar Cepat Tata Bahasa Arab Program 30 Jam: Nahwu, Shorof Sistematis (Yogyakarta: Nurma Media Idea, 2006), h. 152.
} 
Dari permasalahan di atas, maka dibutuhkan sebuah strategi, metode dan teknik belajar baru yang lebih aktif dan menyenangkan. Sebab itu, seorang Dosen dapat menerapkan sebuah strategi kognitif dengan teknik Taking Notes $^{7}$ (membuat catatan) agar Mahasiswa dapat mengambil sebuah kesimpulan dari yang mereka dengar. Dapat juga menggunakan metode pembelajaran model kooperatif seperti metode pembelajaran Kooperatif Tipe Jigsaw, Dosen membuat kelompok yang terdapat di dalamnya beberapa Mahasiswa yang dianggap mempunyai kelebihan yang lebih dari teman lainnya dan diberikan tugas untuk dapat menjelaskan ke teman satu kelompoknya sebagai anggota kelompok. ${ }^{8}$ Ataupun dapat juga menggunakan teknik pembelajaran tipe make a match (mencari pasangan). Adapun kelebihannya adalah siswa berperan aktif dan menyenangkan untuk mencari pasangannya tentang suatu konsep atau topik pembahasan. ${ }^{9}$

Metode Bamboo Dancing adalah suatu teknik pengembangan metode inside outside Circle yaitu dimana seorang guru mengawali pembelajaran dengan mengenalkan topik bahasan. ${ }^{10}$ Dalam penelitian ini, peneliti akan menggunakan tipe Bamboo Dancing dari pembelajaran Kooperatif yaitu dimana Mahasiswa saling berhadapan dengan pasangannya berdiskusi membahas suatu topik atau tema dan saling memberikan informasi yang telah diketahui dalam waktu yang bersamaan dalam proses pelaksanaannya, selanjutnya salah satu mahasiswa bergerak searah jarum jam dan bergantian seterusnya untuk saling membahas dan berbagi informasi dengan saling bertukar pasangan yang baru. ${ }^{11}$

\footnotetext{
${ }^{7}$ Muhammad Syaifullah, “Tatbiq Al-Istiratijiyyah al-Ma'rifiyyah Ma'a Taqniyyati 'Akhdi al-Mulakhadat' Li Tarqiyyati Qudrati al-Tulabah Fi Fahmi al-Nusus al-'Arabiyyah Bi Jami'ah Ma'arif Nahdah al-'Ulama al-Islamiyyah Matru Lambung," Jurnal Al-Bayan: Jurnal Jurusan Pendidikan Bahasa Arab 10, no. 1 (2018): 1-21, https://doi.org/10.24042/albayan.v10i01.2592.

${ }^{8}$ Muhammad Syaifullah, "Pembelajaran Metode Kooperatif Tipe jigsaw Dalam Meningkatkan Hasil Belajar Bahasa Arab (Qowa'id) Mahasiswa Perbankan Syari'ah IAIM NU Metro Lampung Tahun 2017," Jurnal Bahasa Lingua Scientia 9, no. 2 (2017): 177-208, https://doi.org/10.21274/Is.2017.9.2.177-208.

${ }^{9}$ Muhammad Syaifullah, "Pembelajaran Kooperatif Tipe Make A Match Dalam Meningkatkan Penguasaan Kosa Kata Bahasa Arab Santri TPA Al-Barokah Hadimulyo Timur Metro Pusat," At-Ta'dib 11, no. 2 (2016): 305, https://doi.org/10.21111/at-tadib.v11i2.781.

${ }^{10}$ Nelly Ahviena Hifdziyah, "Penerapan Metode Bamboo Dancing Untuk Meningkatkan Hasil Belajar Siswa Kelas V Pada Mata Pelajaran IPS Materi Pokok TokohTokoh Penting Dalam Peristiwa Proklamasi Kemerdekaan Indonesia Di MI Ta'mirul Wathon 01 Sikancil Larangan Brebes" (Skripsi, UIN Walisongo, 2015), h. 10, http://eprints.walisongo.ac.id/5193/.

${ }^{11}$ M. Huda, Model-Model Pengajaran dan Pembelajaran (Yogyakarta: Pustaka Pelajar, 2013), h. 249.
} 
Pemilihan metode Bamboo Dancing kemudian diterapkan karena mempunyai keunggulan yaitu mahasiswa dapat saling berbagi informasi dengan pasangan yang berbeda dalam waktu yang singkat dan teratur sehingga mempunyai banyak kesempatan untuk mengelola informasi serta meningkatkan keterampilan dalam berkomunikasi. Semua mahasiswa terlibat aktif dalam memberi dan menerima informasi dari pasangannya. ${ }^{12}$

\section{B. Metode Penelitian}

Dalam menulis sebuah karya ilmiah sehingga menghasilkan penelitian yang diterapkan secara ilmiah dengan harapan untuk dapat menemukan, memberikan sumbangsih pemikiran dan menyajikan kebenaran. ${ }^{13}$ Begitu juga dalam penulisan artikel penelitian ini, peneliti menggunakan beberapa langkah kerja, di antaranya ialah:

Dalam artikel ini memakai jenis PTK model John Elliot. Subjek pada penelitian ini ialah mahasiswa PBA semester III IAIM NU Metro Lampung Tahun Akademik 2019/2020. Adapun objek penelitian yaitu efektivitas adalah penggunaan metode Bamboo Dancing dalam meningkatkan hasil pemahaman teks qiro'ah (membaca) Mahasiswa PBA IAIM NU Metro Lampung.

Dalam pengumpulan data untuk mendapatkan informasi yang diperlukan, metode pengumpulan data yang diterapkan oleh peneliti yaitu menggunakan: metode wawancara mendalam (interview) berkaitan dengan sesuatu yang telah diperbuat oleh seseorang ${ }^{14}$, Observasi, Dokumentasi untuk mendapatkan data-data terhadap sesuatu bahkan beberapa variabel yang berupa catatan, transkrip, buku dan sebagainya ${ }^{15}$, Analisis data kualitatif. Peneliti menggunakan dua siklus, yang mana setiap siklus terdapat empat tahapan, yaitu: perencanaan, pelaksanaan tindakan, pengamatan, dan refleksi. Masing-masing tahapan dalam Penelitian Tindakan Kelas model John Elliot. ${ }^{16}$

12 Etika Dewayani, “Penerapan Model Pembelajaran Kooperatif Bamboo Dancing (Tari Bambu) Untuk Meningkatkan Hasil Belajar Peserta Didik Pada Pokok Bahasan Teks Faktual IImiah Di Kelas XII MIPA 2 SMA Negeri 2 Pekanbaru," PEKA 5, no. 2 (2017): 161, https://journal.uir.ac.id/index.php/Peka/article/view/1194.

${ }^{13}$ Sutrisno Hadi, Methodologi Riset (Yogyakarta: Fakultas Psikologi UGM, 1991), h. 130.

${ }^{14}$ Lexy J. Moeloeng, Metodologi Penelitian Kualitatif (Bandung: Remaja Rosdakarya, 2006), h. 140.

${ }^{15}$ Suharsimi Arikunto, Prosedur Penelitian Suatu Pendekatan Praktek (Jakarta: Rineka Cipta, 1993), h. 51.

${ }^{16}$ Trianto, Panduan Lengkap Penelitian Tindakan Kelas: Teori dan Praktik (Jakarta: Prestasi Pustakarya, 2011), h. 29. 
Terdapat tiga macam bentuk instrumen digunakan dalam penelitian ini, yakni: (1) soal tes, dilakukan guna mendapatkan suatu pemahaman mahasiswa pada tiap siklus di akhir pembelajaran, (2) lembar observasi, digunakan untuk melakukan pengamatan terhadap dosen terhadap penerapan dari rencana pembelajaran dan kegiatan mahasiswa selama proses belajar mengajar, (3) pedoman wawancara, digunakan untuk mengetahui kegiatan pembelajaran sebelum pemberian tindakan kepada mahasiswa.

Adapun data yang diperoleh akan dianalisis adalah memaparkan dan menganalisa terhadap apa yang menjadi fokus pada penelitian ${ }^{17}$ yaitu melalui langkah-langkah: Pengumpulan data dan pengecekan, Reduksi data, Penyajian data (identifikasi, klasifikasi, penyusunan, penjelasan, dan pemaknaan data), Penyimpulan. ${ }^{18}$

\section{Hasil dan Pembahasan}

1. Proses pembelajaran qiro'ah (membaca) dengan model pembelajaran kooperatif tipe bamboo dancing mahasiswa PBA IAIM NU Metro

\section{a. Tahap Observasi Awal}

\section{1) Deskripsi Data Hasil Observasi Awal}

Observasi awal (pra tindakan) dilakukan sebelum peneliti memulai tindakan kelas dengan melalui kegiatan wawancara kepada Dosen yang bersangkutan yaitu pada mata kuliah Qiro'ah (membaca) dan mahasiswa PBA Institut Agama Islam Ma'arif NU Metro. Berdasarkan observasi peneliti, ditemukan bahwa materi yang digunakan dalam pembelajaran Qiro'ah menggunakan buku ajar Arabiyah Linnasyiin Jilid lima.

Selama ini metode yang diterapkan dalam mata kuliah Qiro'ah seringkali menerapkan metode qowaid wa tarjamah dan metode langsung. Hasilnya, mahasiswa selalu diajarkan untuk menerjemahkan teks bacaan secara langsung kemudian dan kurang memahami isi bacaan secara kontekstual. Hal ini dikarenakan proses pembelajaran bahasa Arab bagi mahasiswa kurang berkesan dan melekat, sehingga mahasiswa mudah lupa dengan apa yang telah dihafalnya. Observasi peneliti terhadap mahasiswa PBA IAIM NU Metro dengan jumlah 11 orang dan mendapatkan hasil belajar mahasiswa yang tergolong rendah. Hasil ini diidentifikasi pada hasil nilai pre-test qiro'ah yang telah dilakukan pada hari Rabu tanggal 18 Desember 2019 masih belum memenuhi KKM.

\footnotetext{
${ }^{17}$ Noeng Muhajir, Metode Penelitian Kualitatif (Yogyakarta: Rake Sarasin, 1998), h.
} 87.

${ }^{18}$ M. B. Milles dan Machael A. Huberman, Analisis Data Kualitatif, trans. oleh Rahendi Rohidii (Jakarta: UI Press, 1992), h. 30. 


\section{2) Refleksi Observasi Awal}

Hasil dari Observasi awal, peneliti menemukan permasalahan pada mahasiswa PBA IAIM NU Metro, yaitu permasalahan dari seorang guru/dosen dalam memilih metode pembelajaran yang kurang tepat dan kurang memperhatikan kebutuhan mahasiswa yang berdampak terhadap hasil pemahaman teks qiro'ah mahasiswa rendah. Dalam hal ini, maka peneliti dapat melakukan perbaikan terhadap proses pembelajaran yang berlangsung di mahasiswa Pendidikan Bahasa Arab IAIM NU yaitu tindakan yang dapat meningkatkan hasil pemahaman teks Qiro'ah mahasiswa. Adapun metode pembelajaran yang dianggap tepat dan bisa diterapkan guna meningkatkan hasil belajar bahasa Arab Qiro'ah mahasiswa adalah pembelajaran kooperatif model Bamboo Dancing yang pelaksanaannya lebih berkesan dan bermakna terhadap memori mahasiswa sehingga diharapkan dapat meningkatkan hasil belajar bahasa Arab Qiro'ah mahasiswa.

\section{b. Hasil Pelaksanaan Tindakan siklus I}

\section{1) Tahap Perencanaan Tindakan}

Tahap ini dilakukan setelah tahap refleksi hasil observasi awal. Kegiatan awal yang dilakukan yaitu merancang pembelajaran untuk siklus 1 dan 2 . Rencana pelaksanaan pembelajaran untuk siklus pertama disusun dengan tema soal yang mudah dalam perlombaan sedangkan siklus kedua dengan tema beasiswa di dalam mimpi (المنة في المنام).

Selanjutnya, menyusun pertanyaan-pertanyaan sesuai dengan tema bahasan. Pertanyaan disusun dalam bentuk essay dan pilihan ganda sesuai dengan tema yang dipelajari, demikian juga dengan soal post test siklus 2 .

Untuk keperluan dalam penyusunan data lembar observasi kegiatan maka terdapat beberapa tahapan; tahap awal, inti, dan akhir proses pembelajaran serta menyiapkan lembaran Observasi untuk kegiatan dosen. Menggunakan lembaran Observasi agar dapat mengukur berjalannya kegiatan proses belajar mengajar yang diterapkan dosen terkait dengan rencana pembelajaran semester. Terakhir adalah menyusun pedoman wawancara untuk dosen dan mahasiswa Pendidikan Bahasa Arab IAIM NU pasca tindakan. Pedoman wawancara ini berfungsi untuk mengetahui tanggapan dosen dan mahasiswa Pendidikan Bahasa Arab IAIM NU mengenai pelaksanaan pembelajaran setelah diterapkannya metode pembelajaran yang baru. 


\section{2) Tahap Pelaksanaan Tindakan 1}

Tahap ini dilaksanakan selama 60 menit. Pertemuan ini dilaksanakan di hari kamis, 19 Desember 2019.

a) Kegiatan awal

Kegiatan diawali dengan, Dosen mengucapkan salam dan kemudian bertanya tentang keadaan mahasiswa. Dosen menunjuk salah satu mahasiswa untuk memimpin do'a. Agar mahasiswa bersemangat dosen memandu mahasiswa untuk bernyanyi bersama dengan lagu hubbul wathan. Setelah terlihat bahwasannya mahasiswa sudah siap untuk memulai kegiatan belajar, dosen terlebih dahulu menginformasikan tema yang akan dipelajari dan tujuan pembelajarannya sebelum tahap penyampaian materi.

b) Kegiatan inti

Kegiatan inti dimulai dengan dosen mengarahkan perhatian mahasiswa ke tema yang akan disampaikan, Dosen mengenalkan topik baru kepada mahasiswa. Dosen dapat menuliskan tema di papan tulis atau Dosen bisa melakukan tanya jawab kepada Mahasiswa mengenai tema akan disampaikan, dengan tema “soal yang mudah dalam perlombaan" (السؤال سهل في المسابقة).

Mahasiswa berdiri berjajar saling berhadapan dengan pasangannya di depan kelas. Mahasiswa yang saling berhadapan dengan pasangannya dari kedua jajaran saling berbagi informasi. Kemudian, satu atau dua Mahasiswa yang berdiri di ujung salah satu jajaran pindah ke ujung lainnya di jajarannya. Mahasiswa kemudian berpindah tempat. Sehingga setiap Mahasiswa mendapatkan pasangan yang baru untuk saling berbagi informasi.

c) Kegiatan Penutup

Alokasi waktu kegiatan ini selama 20 menit. Pada kegiatan yang dilakukan dosen merefleksi dengan mahasiswa mengenai metode bamboo dancing yang telah dilakukan.

Dosen bertanya kepada peserta didik apakah metode pembelajaran bamboo dancing mereka lebih mudah atau semakin sulit dalam memahami bahasa Arab teks qiro'ah. Mahasiswa pun menjawab dengan serentak bahwa mereka merasa pembelajaran bahasa Arab ini terasa lebih muda dipahami. akan tetapi dosen tetap memberi kesempatan bagi mahasiswa yang ingin mengajukan pendapatnya.

Selain merefleksi tentang kesulitan yang dialami mahasiswa dalam belajar, dosen dan mahasiswa juga merefleksi tentang teknis pelaksanaan bamboo dancing. Pada akhir kegiatan 
penutup ini Dosen melakukan postes siklus I. Post-tes ini dilaksanakan selama 20 menit dengan 10 butir soal. 5 butir soal pilihan ganda dan 5 butir soal berikutnya adalah essay.

\section{3) Pengamatan}

Pengamatan dilakukan selama proses pembelajaran berlangsung. Pada tahap ini, peneliti mengamati terhadap aktivitas dan keadaan mahasiswa saat PBM berlangsung. Kemudian dianalisis menggunakan analisis prosentase, dengan kualifikasi; skor 4 sangat baik, skor 3 baik, skor 2 cukup, dan skor 1 kurang. Hasil dari penjumlahan semua skor disebut dengan jumlah skor. Kemudian dihitung nilai rata-rata dengan menggunakan rumus:

Skor Maksimum: 52

Prosentase nilai rata-rata $=\frac{\text { Skor Perolehan }}{\text { Skor Maksimum }} \times 100 \%$

Dari hasil pengamatan pada tindakan siklus I secara garis besar mendapatkan jumlah skor sebesar 38, adapun skor maksimal mendapatkan skor sebesar 52. Dari hasil data ini, jadi prosentase nilai rata-rata yaitu: $\frac{38}{52} \times 100 \%=73 \%$. Hasil observasi yang sudah didapatkan ini dalam proses pembelajaran Mahasiswa termasuk dalam kategori "Baik". Mahasiswa mengikuti proses pembelajaran sudah cukup baik yaitu mengikuti langkah pembelajaran yang dilakukan dosen, serta dapat memperhatikan setiap penjelasan yang disampaikan dosen pun dinilai sangat baik sekali. Akan tetapi, berdasarkan tabel deskriptor di atas, Mahasiswa kurang memperhatikan tujuan pembelajaran. Selain itu mahasiswa juga masih belum mempunyai keberanian untuk menyampaikan pendapatnya, ataupun sekedar bertanya. Berdasarkan hal ini, maka peneliti akan melakukan perbaikan pada siklus berikutnya

\section{4) Tahap Analisis dan Refleksi Tindakan 1}

Dari hasil observasi pada siklus $1 \mathrm{di}$ atas, menunjukkan hasil yang sudah cukup baik dan sesuai dengan apa yang telah dirancang di dalam pembelajaran. Akan lebih baik lagi jika lebih diperbaiki dari segi variasi metode pembelajaran dan ketepatan waktu selama proses belajar mengajar berlangsung, supaya terciptanya suasana yang aktif dan menyenangkan dalam proses belajar mengajar.

Adapun hasil dapat diketahui dari nilai rata-rata tes yang mencakup penguasaan dalam pemahaman teks dari Qiro'ah (membaca) sebelum diterapkannya pembelajaran kooperatif tipe bamboo dancing sebesar 67 dengan prosentase adalah $67 \%$. Sedangkan setelah diterapkan pembelajaran kooperatif tipe bamboo 
dancing ini, rata-rata nilai dari tes akhir pada siklus 1 sebesar 79 dalam prosentase $79 \%$.

Kesimpulan yang dapat diambil dari hasil nilai di atas adalah bahwa proses adaptasi dan sosialisasi berjalan baik walaupun terdapat beberapa peserta didik masih kurang semangat untuk mengikuti model kegiatan yang diterapkan Dosen. Penyebabnya yaitu Mahasiswa belum terbiasa menggunakan variasi-variasi pembelajaran baru yang diterapkan dalam pembelajaran Qiro'ah. Adapun permasalahan untuk menerapkan metode bamboo dancing ini, suasana kelas berubah gaduh dan ramai. Akan tetapi dalam pelaksanaan pembelajaran model bamboo dancing semua mahasiswa sangat antusias, dan berperan aktif saat PBM berlangsung.

\section{c. Hasil Pelaksanaan Siklus 2}

\section{1) Tahap Perencanaan Tindakan}

Pelaksanaan pada siklus kedua ini sebenarnya telah diterapkan bersama perencanaan siklus pertama, hanya pada siklus kedua dilakukan perbaikan dari siklus pertama sebagaimana refleksi yang dilakukan dari temuan pada siklus 1 .

\section{2) Tahap Pelaksanaan Tindakan}

Pada hari Senin, 23 Desember 2019 siklus II diterapkan dengan durasi waktu selama 60 menit.

a) Kegiatan awal

Di awal kegiatan, Dosen mengucapkan salam dan kemudian bertanya tentang keadaan mahasiswa. Dosen menunjuk salah satu mahasiswa untuk memimpin do'a. Agar mahasiswa bersemangat dosen memandu mahasiswa untuk bernyanyi bersama dengan lagu hubbul wathan. Setelah terlihat bahwasannya mahasiswa sudah siap untuk memulai kegiatan belajar, dosen terlebih dahulu menginformasikan tema yang akan dipelajari dan tujuan pembelajarannya sebelum tahap penyampaian materi.

b) Kegiatan inti

Kegiatan inti dimulai dengan dosen mengarahkan perhatian mahasiswa ke tema yang akan disampaikan, Dosen mengenalkan topik baru kepada mahasiswa. Dosen dapat menuliskan tema di papan tulis atau Dosen bisa melakukan tanya jawab kepada Mahasiswa mengenai tema akan disampaikan, dengan tema "beasiswa dalam mimpi" (المحنة في المنام).

Mahasiswa berdiri berjajar saling berhadapan dengan pasangannya di depan kelas. Mahasiswa yang saling berhadapan dengan pasangannya dari kedua jajaran saling berbagi informasi. Kemudian, satu atau dua Mahasiswa yang berdiri di ujung salah 
satu jajaran pindah ke ujung lainnya di jajarannya. Mahasiswa kemudian berpindah tempat. Sehingga setiap Mahasiswa mendapatkan pasangan yang baru untuk saling berbagi informasi.

c) Kegiatan Penutup

Pada kegiatan penutup berjalan selama 20 menit. Dosen merefleksi bersama mahasiswa mengenai metode bamboo dancing yang dilakukan. Dosen bertanya kepada peserta didik apakah dalam model pembelajaran bamboo dancing mereka lebih mudah atau semakin sulit dalam memahami bahasa Arab teks qiro'ah. Mahasiswa pun menjawab dengan serentak bahwa mereka merasa pembelajaran bahasa Arab ini terasa lebih muda dipahami. akan tetapi dosen tetap memberi kesempatan bagi mahasiswa yang ingin mengajukan pendapatnya.

Selain merefleksi tentang kesulitan yang dialami mahasiswa dalam belajar, Dosen dan Mahasiswa juga merefleksi tentang teknis pelaksanaan bamboo dancing. Pada akhir kegiatan penutup ini dosen melakukan postes siklus 1 . Postes ini dilaksanakan dalam waktu 20 menit untuk 10 butir soal. 5 butir soal pilihan ganda dan 5 butir soal berikutnya adalah essay.

Waktu 5 menit telah habis digunakan sesi refleksi, sehingga tidak cukup waktu untuk dilakukan post test, untuk itu post tes akan dilaksanakan pada hari berikutnya yaitu hari selasa tanggal 24 Desember 2019.

d) Post tes siklus 2

Post test dilaksanakan selama 20 menit untuk 10 butir soal, 5 butir soal pilihan ganda dengan pemahaman teks Qiro'ah dan 5 butir soal berikutnya adalah essay.

\section{3) Pengamatan atau Observasi}

Dari hasil pengamatan pada tindakan siklus II secara garis besar mendapatkan jumlah skor sebesar 49, adapun skor maksimal mendapatkan skor sebesar 52. Dari hasil data ini, jadi prosentase nilai rata-rata yaitu: $\frac{49}{52} \times 100 \%=94 \%$. Hasil observasi yang sudah didapatkan ini dalam proses pembelajaran Mahasiswa masuk pada kategori "Sangat Baik". Mahasiswa mengikuti proses pembelajaran sudah cukup baik yaitu mengikuti langkah pembelajaran yang dilakukan dosen, serta dapat memperhatikan setiap penjelasan yang disampaikan dosen pun dinilai sangat baik sekali. Dalam tahapan siklus II ini, mahasiswa sudah cukup baik memperhatikan tujuan pembelajaran yang telah disampaikan oleh dosen. Mahasiswa juga sudah mempunyai keberanian untuk untuk bertanya dan bahkan menyampaikan pendapatnya. 


\section{4) Tahap Analisis dan Refleksi Tindakan 2}

Dari hasil observasi pada siklus II di atas, menunjukkan hasil yang sudah cukup baik dan sesuai dengan apa yang telah dirancang di dalam pembelajaran. Dosen melakukan perbaikan dari segi variasi metode pembelajaran dan ketepatan waktu pada saat belajar mengajar berlangsung, agar terciptanya keadaan yang aktif dan menyenangkan pada proses pembelajaran sehingga berdampak terhadap respon dari Mahasiswa dengan hasil persentasenya juga meningkat.

Adapun hasil yang telah diketahui yaitu nilai rata-rata dari tes mencakup penguasaan dalam pemahaman teks dari Qiro'ah (membaca) setelah diterapkan metode bamboo dancing ini yaitu sebesar 91 pada prosentase adalah 91\%. Pembelajaran yang dilakukan juga sudah melibatkan lebih banyak mahasiswa yang pada siklus I belum bersedia berpartisipasi dan enggan untuk berbicara menyampaikan pendapat, pada siklus II ini sudah dapat berpartisipasi dan lebih aktif lagi.

Menurut hasil wawancara beberapa Mahasiswa, baik dari sebelum tindakan dan setelah tindakan, dinyatakan lebih baik dari siklus 1. Pernyataan ini diketahui dari jawaban Mahasiswa ketika ditanya terhadap kesannya dalam PBM yang telah diterapkan, dengan jawaban sebagian besar mereka menyatakan bahwa PBM lebih menyenangkan, apalagi setelah diselingi dengan metode permainan. Ketika ditanya tentang pembelajaran Qiro'ah (membaca) menggunakan model bamboo dancing, mereka menjawab bahwa pembelajaran bahasa Arab Qiro'ah menjadi lebih mudah dan menyenangkan. Karena dalam pembelajaran model bamboo dancing mereka bisa belajar sambil bermain.

Untuk mengetahui apakah penerapan pada siklus II dinyatakan berhasil ataupun belum yang didasarkan pada analisis data observasi yang dilakukan terhadap kegiatan Dosen dan Mahasiswa dengan melakukan refleksi. Hasil refleksi menunjukkan taraf keberhasilan dalam kategori "A" (sangat baik). Siklus II ini Mahasiswa lebih berani dan percaya diri untuk bertanya dan mengemukakan pendapat.

Dengan adanya peningkatan dari keaktifan dan pemahaman teks Qiro'ah Mahasiswa setelah diterapkan pada siklus 2 berdasarkan dari hasil post tes dan observasi, maka penerapan pembelajaran kooperatif model bamboo dancing dalam materi beasiswa di dalam mimpi المنة في المنام untuk meningkatkan pemahaman teks Qiro'ah maka siklus 2 ini dianggap cukup. 


\section{Hasil Peningkatan Pemahaman Teks Qiro'ah Mahasiswa PBA IAIM} NU Metro dengan Menerapkan Metode Bamboo Dancing

Setelah dilakukan analisis tes dan wawancara pada setiap siklus, maka dapat diambil kesimpulan, bahwa:

\section{a. Siklus I}

Hasil dari peningkatan pemahaman teks Qiro'ah setelah diterapkannya metode bamboo dancing kepada 11 Mahasiswa. Dapat dilihat dari data hasil post test berikut ini dengan KKM sebesar 70 .

Tabel Prosentase Tes Peningkatan Pemahaman Teks Qiro'ah dalam Siklus I

\begin{tabular}{|c|c|c|c|}
\hline Jumlah mahasiswa & Hasil skor rata-rata & Persentase & Persentase ketuntasan \\
\hline 11 & 79 & $79 \%$ & $85 \%$ \\
\hline
\end{tabular}

\section{b. Siklus II}

Hasil dari siklus II dapat dilihat dari data hasil post test pada tabel di bawah ini dengan KKM sebesar 70 .

Tabel Prosentase Tes Hasil Belajar Mahasiswa Pada Siklus II

\begin{tabular}{|c|c|c|c|}
\hline Jumlah mahasiswa & Hasil skor rata-rata & Persentase & Persentase ketuntasan \\
\hline 11 & 91 & $91 \%$ & $100 \%$ \\
\hline
\end{tabular}

Data lain dari hasil wawancara terhadap Mahasiswa yang menyatakan bahwa dengan penerapan metode bamboo dancing ini Mahasiswa dapat memahami teks Qiro'ah dengan mudah dan menyenangkan.

\section{c. Perbandingan Siklus I dan II}

Perbandingan dari hasil nilai pada siklus I dan II, diketahui bahwa pemahaman teks Qiro'ah terjadi peningkatan.

Tabel Perbandingan Hasil Post Test Mahasiswa Pada Siklus 1 \& 2

\begin{tabular}{|c|c|c|}
\hline HP 1 & HP 2 & $\begin{array}{c}\text { Peningkatan (\%) } \\
\text { HP1 ke HP2 }\end{array}$ \\
\hline 79 & 91 & $12 \%$ \\
\hline
\end{tabular}

Ket:

HP 1 : rata-rata hasil post test siklus 1

HP 2 : rata-rata hasil post test siklus 2

Berdasarkan tabel di atas diketahui bahwa persentase rata-rata hasil post test pada pemahaman teks Qiro'ah terjadi peningkatan dari siklus 1 ke siklus 2 yaitu sebesar $12 \%$. 


\section{Kesimpulan}

Penerapan metode bamboo dancing pada mata kuliah Qiro'ah (membaca) pada siklus 1 ditemukan beberapa permasalahan; kurangnya waktu yang dialokasikan Dosen untuk sesi demonstrasi dan Mahasiswa masih merasa takut untuk mengungkapkan pendapatnya. Sedangkan pada siklus 2, semua masalah ini sudah teratasi. Penguasaan pemahaman teks Qiro'ah (membaca) Mahasiswa dengan tipe bamboo dancing ini terjadi peningkatan dari siklus 1 ke siklus 2 . Hal ini berdasarkan dari hasil post test di setiap siklusnya. Dari hasil tersebut, kesimpulan yang diambil adalah bahwa dengan menerapkan metode bamboo dencing bisa memberikan manfaat bagi Mahasiswa, antara lain yaitu; mampu membuat keadaan belajar mengajar yang aktif serta menyenangkan, terdapat peningkatan dalam penguasaan pemahaman teks Qiro'ah (membaca) Mahasiswa dengan tidak menerapkan metode terjamah yang tidak disenangi mahasiswa. 


\section{Daftar Pustaka}

Arikunto, Suharsimi. Prosedur Penelitian Suatu Pendekatan Praktek. Jakarta:

Rineka Cipta, 1993.

Dewayani, Etika. "Penerapan Model Pembelajaran Kooperatif Bamboo Dancing

(Tari Bambu) Untuk Meningkatkan Hasil Belajar Peserta Didik Pada Pokok

Bahasan Teks Faktual IImiah Di Kelas XII MIPA 2 SMA Negeri 2 Pekanbaru."

PEKA 5, no. 2 (2017): 161.

https://journal.uir.ac.id/index.php/Peka/article/view/1194.

Fauzi, Umar. "Pembentukan Kemampuan Berbahasa Pada Anak Usia Prasekolah

(Studi Deskriftif Tentang Pengenalan Bahasa Arab Sejak Dini." Skripsi,

STAIN Purwokerto, 2003.

Hadi, Sutrisno. Methodologi Riset. Yogyakarta: Fakultas Psikologi UGM, 1991.

Hifdziyah, Nelly Ahviena. "Penerapan Metode Bamboo Dancing Untuk

Meningkatkan Hasil Belajar Siswa Kelas V Pada Mata Pelajaran IPS Materi

Pokok Tokoh-Tokoh Penting Dalam Peristiwa Proklamasi Kemerdekaan

Indonesia Di MI Ta'mirul Wathon 01 Sikancil Larangan Brebes." Skripsi, UIN

Walisongo, 2015. http://eprints.walisongo.ac.id/5193/.

Huda, M. Model-Model Pengajaran dan Pembelajaran. Yogyakarta: Pustaka

Pelajar, 2013.

Joys, Bruce, Marsha Weil, dan Emily Calhoun. Models of Teaching. Yogyakarta:

Pustaka Pelajar, 2009.

Makmun, A. Samsuddin. Psikologi Kependidikan. Bandung: Remaja Rosdakarya, 2009.

Milles, M. B., dan Machael A. Huberman. Analisis Data Kualitatif. Diterjemahkan oleh Rahendi Rohidii. Jakarta: UI Press, 1992.

Moeloeng, Lexy J. Metodologi Penelitian Kualitatif. Bandung: Remaja Rosdakarya, 2006.

Muhajir, Noeng. Metode Penelitian Kualitatif. Yogyakarta: Rake Sarasin, 1998.

Munawari, A. Belajar Cepat Tata Bahasa Arab Program 30 Jam: Nahwu, Shorof Sistematis. Yogyakarta: Nurma Media Idea, 2006.

Syaifullah, Muhammad. "Pembelajaran Kooperatif Tipe Make A Match Dalam Meningkatkan Penguasaan Kosa Kata Bahasa Arab Santri TPA Al-Barokah Hadimulyo Timur Metro Pusat." At-Ta'dib 11, no. 2 (2016): 305.

https://doi.org/10.21111/at-tadib.v11i2.781.

- - - "Pembelajaran Metode Kooperatif Tipe jigsaw Dalam Meningkatkan Hasil Belajar Bahasa Arab (Qowa'id) Mahasiswa Perbankan Syari'ah IAIM NU Metro Lampung Tahun 2017." Jurnal Bahasa Lingua Scientia 9, no. 2 (2017): 177-208. https://doi.org/10.21274/Is.2017.9.2.177-208.

- - - "Penerapan Metode An-Nahdliyah Di TPQ Al-Barokah Dan Metode Iqra' Di TPQ Al-Ikhlas Hadimulyo Timur Metro Pusat Lampung Dalam Kemampuan Membaca Al-Qur'an." Jurnal Iqra' : Kajian Ilmu Pendidikan 2, no. 1 (2017): 131-64. https://doi.org/10.25217/ji.v2i1.96. 
16 | Muhammad Syaifullah, Nailul Izzah, Hernisawati

- - . "Tatbiq Al-Istiratijiyyah al-Ma'rifiyyah Ma'a Taqniyyati ‘Akhdi alMulakhadat' Li Tarqiyyati Qudrati al-Tulabah Fi Fahmi al-Nusus al'Arabiyyah Bi Jami'ah Ma'arif Nahdah al-'Ulama al-Islamiyyah Matru Lambung." Jurnal Al-Bayan: Jurnal Jurusan Pendidikan Bahasa Arab 10, no. 1 (2018): 1-21. https://doi.org/10.24042/albayan.v10i01.2592.

Trianto. Panduan Lengkap Penelitian Tindakan Kelas: Teori dan Praktik. Jakarta: Prestasi Pustakarya, 2011.

Yusuf, Tayar, dan Syaiful Anwar. Metodologi Pengajaran Agama dan Bahasa Arab. Jakarta: Raja Grafindo Persada, 1997. 